DOI: 10.2478/RAE-2019-0010 Review of Artistic Education no. 172019 100-105

\title{
10. THE PIANO, A PERFECT MUSICAL INSTRUMENT - BEGINNINGS AND EVOLUTION (18TH - 19TH CENTURIES)
}

Brînduşa Tudor ${ }^{101}$

\begin{abstract}
The $18^{\text {th }}$ century and the beginning of the $19^{\text {th }}$ century mark the emergence, development and affirmation of the piano as a complex instrument that shall take, in turns, the role of soloist instrument, claiming and being able to reach the sound variety of the orchestra, that of partner in chamber music assemblies or that of orchestra member. The emergence, improvement and qualitative performance acquisition adventure of the piano represents a fascinating history about human creativity and ingenuity serving art, beauty, sound expressivity refinement and improvement.
\end{abstract}

Key words: piano, $18^{\text {th }}$ century, $19^{\text {th }}$ century, piano emergence, piano improvement

\section{Introduction}

„The piano of today is, unquestionably, the most perfect, and consequently the most popular and beloved of all musical instruments" according to the statements made by Jerry Cree Fischer in $1907^{102}$. Even if it was made at the beginning of the 20th century, this statement is perfectly valid today. The emergence, improvement and qualitative performance acquisition adventure of the piano represents a fascinating history about human creativity and ingenuity serving art, beauty, sound expressivity refinement and improvement.

In the 18th century, at the European level a large number of attempts were made in order to improve the quality of the harpsichord sound, but the pinching of chords as a way to obtain it obstructed and limited the finding some solutions capable of improving expressivity at the level of high spiritual requirements of the time. The minimal touch of the clavichord sound expressivity, that so appreciated by Johann Sebastian Bach, was exceeded as soon as harpsichord was built. The quest for some solution through the sound may be increased or decreased and therefore the harpsichord may become an instrument likely to offer sound expressivity and singability, sparked imagination and stimulated the creativity of many musical instrument makers of Europe and then of those of America.

\section{Discussions}

In the musical life of the $18^{\text {th }}$ century, the evolution of piano and therefore that of the affirmation of certain music genres, was determined by the making of

\footnotetext{
${ }^{101}$ Lecturer PhD., "George Enescu” National University of Arts from Iaşi, Romania, email: tudorbrindusa@yahoo.com

${ }^{102}$ Jerry Cree Fischer, Piano Tuning, 1907, Ediţia BiblioLife, 2009, p. 14
} 
the first pianoforte instrument in 1709 by the Italian Bartolomeo Cristofori (1655-1731), that was to become the starting point and the reason behind the occurrence of a real specialised industry. Concerned with achieving optimal sonority, in order to allow the obtaining the piano and forte tones just by a differentiated touch of the keys, in an attempt made at joining volume together with control, Bartolomeo Cristofori invents this new musical instrument. What imposes him as the creator of the first piano is the invention of the exhaust mechanism, that allowed the gavel to come back rapidly to the initial position after hitting the chord allowing it to vibrate. Contemporary of Guarnièrius del Gesù and Antonio Stradivarius, Bartolomeo Cristofori also came from that part of the middle educated characterised by intelligence and ingenuity. The new instrument invented by Bartolomeo Cristofori was quickly popularised rapid and made famous thanks to an article equally enthusiastic and well documented, written by the Italian art critic Scipione Maffei (1675 - 1755), as well as thanks to the relationship and communication networks that used to operate at the level of the various groups or social strata: aristocracy or bourgeoisie, music composers and amateurs.

Even if all throughout Europe, a large number of harpsichord makers ventured into the making of pianos, only some of them actually took part in finding optimal form and sonorities. Contemporary of Bartolomeo Cristofori, Gottfried Silbermann (1683 - 1753) had the idea of applying exhaust mechanics to a clavichord. Having just started out the making of pianoforte and in the process of gathering knowledge, he uses all the observations made to him by Johann Sebastian Bach $^{103}$. By the improvements he brought, Gottfried Silbermann manages to obtain a higher variety of timbre colours. He created a real school of piano makers, some of the most important disciples that contributed to the piano evolution including: Johann Andreas Silbermann, Johann Andreas Stein, Johann Zumpe, Americus Backers. They brought new technical contributions for the much dreamed of sound diversity.

Johann Andreas Stein $(1728-1792)^{104}$ is the one that manages to arrange the German mechanics invented and released by Johann Andreas Silbermann (1712 - 1783), a mechanism, which shall continue its own continuous form of development on the Strasburg - Augsburg - Vienna lode, being the one known as German or Viennese mechanics"105. Apart from Johann Andreas Stein, the Viennese school of piano makers has as representatives Nannette Streicher $(1769-1833)^{106}$ and her brother Carl Andreas Stein (1797 - 1863), Conrad Graf

\footnotetext{
103 „It is a first collaboration between a pianoforte builder and a virtuoso musician - I state that it is the first one because, throughout its development and completion, the piano shall encounter such fruitful collaborations and suggestions coming from the interpreter composers." - Afrodita Popa, Pianofortele în oglinda timpului său. Polifonii culturale, Bucureşti, Editura muzicală, 1994, p. 63

${ }_{104}$ Johann (Georg) Andreas Stein takes responsibility for the design of the so-called Viennese fortepiano, an instrument for which Haydn, Mozart and Beethoven composed (the first opuses), $C f$. http://en.wikipedia.org

${ }^{105}$ Afrodita Popa, op. cit., p. 80

${ }^{106}$ Nannette Streicher (1769 - 1833) - piano maker, pianist, composer, writer, daughter of Johann Andreas Stein, Cf. http://en.wikipedia.org
} 
(1782-1851) ${ }^{107}$, Ignaz Bösendorfer (1794 - 1859), in their workshop being manufactured some instruments that were appreciated by Ludwig van Beethoven, Franz Schubert and others.

The pianos manufactured by Ignaz Bösendorfer gains the admiration of the interpreter-composers for the improvements brought at the sound level: the soft sound but with sufficient power. Bösendorfer introduces the iron frame, crossed chords, which contributed to obtaining a sound with a higher brightness and flexibility. The young Franz Liszt was fascinated by the equal, warm sound of these pianos. The appreciation of these instruments, real jewelleries for the production of sounds was not waited for too much time, winning the highest social level ${ }^{108}$. Bösendorfer realizes that the best advertising agent is precisely the sound of his pianos and this is why in order to persuade his perspective buyers, he shall build a concert hall with 200 seats in 1860 in the new factory located in Neu-Wien. He has resounding success, his manufacture grows up, he changes the factory's location and in 1872 he inaugurates the second concert hall counting 600 seats with a concert directed by Hans von Büllow which was attended by Franz Liszt and Richard Strauss. Ludwig Bösendorfer, son of Ignaz, is the first to have the idea of organising in 1889 the first edition of Bösendorfer Piano Competition and the first ranked competitor is offered a piano made by the company as a prize.

In London, Johann Zumpe ${ }^{109}$ (Johann Christoph - 1726 - 1790) manufactures and manages to impose the small piano of rectangular form, with an easily simplified mechanics and sound amplification pedals. The affordable price shall ensure a wide spread and popularity among middle-class. The one that showed this type of piano to good advantage imposing it as a soloist instrument in the concert halls of London in the 1760s, was the famous interpreter-composer Johann Christian Bach, appreciated for his great fine performances. Americus Backers $(1726-1790)^{110}$ improves the English mechanics by providing it with the exhaust invented by Bartolomeo Cristofori and lost on the way by the other pianoforte makers. Together with William Stodart and John Broadwood, he arranges the English mechanics that Stodart applied in 1777 to a chord instrument called Grand Piano.

In order to build the piano body, John Broadwood $(1732-1812)^{111}$ gives up some parts made of wood, replacing them by metal ones. An interesting fact

\footnotetext{
${ }^{107}$ Conrad Graf was one of the first piano makers to manufacture instruments with Viennese mechanics on an industrial scale, $C f$. http://en.wikipedia.org

${ }^{108}$ In 1869 at the diplomatic reception offered after the signing of the Cooperation Treaty between the AustroHungarian Empire and the Japanese Empire, the Emperor Franz Iosif I provided the Emperor of Japan with a Bösendorfer piano. By the end of the $19^{\text {th }}$ century, Bösendorfer pianos shall get to many imperial courts: Queen Elisabeth of Great Britain, Empress Eugenie of France, the Tsar of Russia.

${ }^{109}$ Johannes (Johann Christoph) Zumpe - the sound made by the pianos resembled that made by harpsichords, but it is sweeter. They would have a silencer on the left side of the sounding board, $C f$. http://en.wikipedia.org

110 Americus Backers laid the foundations of the modern design for today's concert piano, $C f$. http://en.wikipedia.org

${ }_{111}$ John Broadwood is the founder of the famous production of pianos Broadwood and Sons, $C f$. http://en.wikipedia.org
} 
is that Broadwood used each time three cords to obtain a sound of the medium and high register, and in the lower register he used but two ones, the chords being different in terms of length and thickness, depending on height. At the same time, he is the first to use two pedals in a clear and consistent manner: one to lift silencers (patented in 1783) and one for soft music (una corda). Upon the request of Jan Ladislav Dusssek (1760-1812), both composer and pianist, he expands in the high register the piano ambitus to five octaves and a half and later on in bass voice with another fifth. The pianos manufactured by Broadwood company brought to the limelight the splendour and powerful sound made by some robust instruments appreciated by Josef Haydn, Ludwig van Beethoven $^{112}$, Franz Liszt, Frederic Chopin.

Sébastien Érard $(1752$ - 1831) is the first instrument maker to provide the piano with pedals according to the ones used by the harp: one is used for support, one is used for sonority change, one is used for obtaining a celesta sound, one with a bassoon sound and one with a silencer function. He also improves the English mechanics by using the double exhaust (patient in 1821) and therefore he offers composers and interpreters a new challenge: the possibility to quickly repeat the same sound. Another representative of the piano French makers, Jean Henri Pape $(1787-1875)$ brings new innovations by using the crossed chord system (1828) and covering gavels with felt in order to obtain equal sonority, which is superior from the qualitative point of view.

On the other shore of the Atlantic Ocean, in America, the piano manufacture developed thanks to some talented makers. We mention here a few personalities that marked this evolution: Alpheus Babcock $(1785-1842)^{113}$ using a cast iron board (1825) of one single piece that may stand the strength caused by the stretching of the chords. In 1800 John Isaac Hawkins (1772-1854) of Philadelphia obtains the patent for the upright piano called pianino ${ }^{114}$, an instrument that shall be offered improvements focusing on the reaction speed upon touching the keys by Robert Wornum in London and Ignaz Pleyel in Paris. In Boston upon the suggestion made by Alpheus Babcock, Jonas Chickering (1798 - 1853) starts the manufacture of upright pianos with cast iron framework in 1840 .

One year after the establishment of his company, in 1855, Henry Steinway ${ }^{115}$ imposes on the world market upon exhibiting in New York big pianos with oversized chords that were balanced due to a metallic frame so as to be able to produce the intended sound quality and volume. One by one, Steinway prototypes come with new improvements: a new frame model for

\footnotetext{
${ }^{112}$ In 1817 Broadwood sent to Beethoven a piano with two types of pedals with separate silencers for the two registers, high and low.

${ }^{113}$ Alpheus Babcock becomes the greatest piano manufacturer in the United States, patents the „crossed chords” and covering of gavels with textile material.

${ }^{114}$ In 1780 Johann Schmidt of Salzburg manufactures the first upright piano called pianino.

${ }^{115}$ Steinway, Henry E. (1797 - 1871) piano manufacturer, founder of the famous Steinway\&Sons company. He was born in Germany and given the name of Heinrich Engelhard Steinweg.
} 
concert pianos, a new chord crossing model that contributed to the increase of the sound harmonic number- sonority being beneficial, a modified sounding board, sounding boards made of carefully chosen and most of all specially treated types of wood. "The year 1862 marks the appearance of the first Steinway piano which embodied all the technical novelties, including the ones based on the vibration experiences of Helmholz" Afrodita Popa states ${ }^{116}$. During the second half of the $19^{\text {th }}$ century in Europe another two companies manufacturing Bechstein ${ }^{117}$ and Blüthner ${ }^{118}$ pianos become famous and they imposed themselves thanks to the sound qualities of the manufactured instruments.

\section{Conclusions}

The piano reached its full maturity stage, and its evolution was a successful one. It is obvious that the, $19^{\text {th }}$ century was almost completely under the piano sign. And this was not merely due to the fact that the instrument reached its maturity stage, attracting the most numerous followers of that time society, but also due to the fact that (with few exceptions) all the composers were pianists, concert performers, creating the broadest instrumental literature known so far and implicitly developing a pianist technique led to the impossible limits, with expressive valences of a great colour variety and of a sensitivity and freedom fully competing against the harmonic and dynamic timbre play of the romantic orchestral fantasy". 119

Each innovation was determined by a need that emerged in the sound reality and required by both composers and interpreters, and each technical achievement was used and promoted in their artistic activity. The $18^{\text {th }}$ century and the beginning of the $19^{\text {th }}$ century mark the emergence, development and affirmation of the piano as a complex instrument that shall take, in turns, the role of soloist instrument, claiming and being able to reach the sound variety of the orchestra, that of partner in chamber music assemblies or that of orchestra member.

\footnotetext{
${ }^{116}$ Popa, Afrodita - Pianofortele în oglinda timpului său. Polifonii culturale, Editura muzicală a Uniunii Compozitorilor şi Muzicologilor din România, Bucureşti, 1994, p. 226

${ }^{117}$ Bechstein, Carl (1826 - 1900) German piano manufacturer appreciated by Franz Liszt and Claude Debussy. He built the first piano in 1853. In only ten years of existence, he succeeded in manufacturing 400 pianos on a yearly basis.

${ }^{118}$ Blüthner, Julius (1824 - 1910) performs at Leipzig. After many years of apprenticeship by the side of many instrument makers, in 1853 he builds the first piano which shall be appreciated by the bourgeoisie fond of music due to its qualities and especially to its price.

${ }^{119}$ Popa, Afrodita - op. cit., p. 228
} 


\section{References}

1. *** Enciclopedia Universală Britannica, (2010), volumul 2, Editura Litera, Bucureşti

2. Fischer, Jerry Cree, (2009), Piano Tuning, Ediţia BiblioLife

3. Gâscă, Nicolae, (1988), Tratat de teoria instrumentelor, Editura Muzicală, București

4. Gillespie, John, (1972), Five centuries of keyboard music: an historical survey of music for harpsichord and piano, Courier Dover Publications

5. Popa, Afrodita, (1994), Pianofortele în oglinda timpului său. Polifonii culturale, Editura Muzicală a Uniunii Compozitorilor şi Muzicologilor din România, Bucureşti

Web pages:

1. http://en.wikipedia.org

2. https://www.piano-keyboard-guide.com/history-of-the-piano.html 